Etikonomi

Volume 15 (1), April 2016

P-ISSN: 1412-8969; E-ISSN: 2461-0771

Page 43- 62

\title{
THE IMPACT OF LITERACY TO SHARIAH FINANCIAL SERVICE PREFERENCES
}

\author{
Anna Sardiana \\ Indonesia Banking School \\ a.sardiana@gmail.com
}

\begin{abstract}
.
The purpose of this study was to determine whether the Islamic financial literacy and the indicator as the knowledge, ability or skills and the confidence have a significant effect together and partially to the preferences of using the Islamic financial services. This type of research is descriptive research, while the method of analysis used in this study is the method of binary logistic regression analysis. The data used is primary data by the method of distributing questionnaires to users and non-users of Islamic financial services in Jakarta spread to the period April to May 2014. The results of this study indicate that Islamic financial literacy significant influence preference use Islamic financial services. In further testing, the knowledge indicator is partially significant toward the preferences of the use of Islamic financial services, as for indicators of ability and confidence does not affect the preferences of the use of Islamic financial services.
\end{abstract}

Keywords: Islamic financial literacy; preferences; usage of financial services

\begin{abstract}
Abstrak.
Tujuan dari penelitian ini adalah untuk menentukan apakah melek keuangan Islam dan indikator sebagai pengetahuan, kemampuan atau keterampilan dan kepercayaan diri memiliki efek yang signifikan bersama-sama dan parsial terhadap preferensi menggunakan jasa keuangan Islam. Jenis penelitian ini adalah penelitian deskriptif, sedangkan metode analisis yang digunakan dalam penelitian ini adalah metode analisis regresi logistik biner. Data yang digunakan adalah data primer dengan metode penyebaran kuesioner kepada pengguna dan non-pengguna layanan keuangan Islam di Jakarta pada periode April-Mei 2014. Hasil penelitian ini menunjukkan bahwa melek keuangan Islam berpengaruh signifikan terhadap penggunaan jasa keuangan Islam. Dalam pengujian lebih lanjut, indikator pengetahuan sebagian signifikan terhadap preferensi penggunaan layanan keuangan Islam, indikator kemampuan dan kepercayaan diri tidak mempengaruhi preferensi penggunaan layanan keuangan Islam.
\end{abstract}

Kata Kunci: melek keuangan Islam; preferensi; penggunaan jasa keuangan Islam

Received: January 3, 2016; Revised: February 10, 2016; Approved: March 12, 2016 
The Impact of Literacy to Shariah Financial Service Preferences

Anna Sardiana

\section{INTRODUCTION}

From 1971 to 2010, total population number in Indonesia showed a growth rate relatively high as an average of $1.78 \%$ per year compared to the world population growth was 1.61\%. In 2010, total population of Indonesia has reached 237.64 million. With this growth, the community needs regarding financial products and services are also expected increase from year to year. On the other side, the number of people in productive age (15-54 years) reached $59.98 \%$ or 142.54 million (BPS, 2012). This population group is a very potential segment for financial services institutions to offer financial products and services according to their needs.

Along with the increasing number of people, economic growth that is relatively stable in the last ten years, with average growth is above 5\% per year, representing the number of poor citizens decreased and it can be interpreted that the level of Indonesian welfare has been increasing or progressing from time to time. At the same time on the improvement of prosperity, then potential of financial product and service needs in Indonesian society will be expected increase from both sides of the number and its diversity.

The growth of Indonesia Gross Domestic Product (GDP) does not escape from the role and contribution of financial services. However, despite this service sector has been doing financial intermediary role as a whole, the role is still not optimal. This can be seen from the contribution of financial industry shared in Indonesia GDP. The potential of Indonesian societies that will take a financial products and services advantage in the future are expected to be increased, considering of GDP per capita growth is from Rp6.72 million in 2000 to Rp33.34 million in 2012. The growth is not detached from the important role and contribution of the financial services sector in Indonesia who were doing financial intermediation Rp7.534.81 trillion per December 2012. However, compared to Southeast Asia countries, the role is still not optimal (OJK, 2013). Beside of the spread of financial services institution factor that have not been distributed in all regions in Indonesia, and also not all the societies can utilize the financial products and services. This happened 
because in general, the societies still have a perception that it is difficult to meet minimum requirements to obtain financial products and services. They not understand the function and benefits of financial products and services. Their education levels are less sufficient to reach some financial products and services especially for low-income people and still have difficulties in accessing financial products and services since limited on infrastructure.

Hence, it can be seen that the knowledge and understanding of the societies about the financial products and services has not optimal yet. It is supported by a survey from Bank of Indonesia, about Indonesian society financial literacy. Comparing to neighboring countries, the level of good literacy in Indonesia is only 20\%. Different from Philippines reached 27\%, Malaysia $37 \%$, Singapore 98\%, respectively (OJK, 2013). These show that Indonesia has a low financial literacy, both in national and global level.

Related to this in the first semester of 2013, Financial Services Authority (OJK) does a financial literacy national survey in 20 provinces by involving a number of respondents as much as 8,000 people. Based on the survey, it is used the financial literacy index and financial products and services utility index. Financial literacy index also provides information about the features knowledge level of societies, benefits and risks as well as their rights and obligations as a user of financial products and services.

On the financial products and services utility index survey that is a parameter or indicators to measure how many Indonesian people utilizing the financial products and services, shows the result about 59.74\%. However, financial products and services utilities are not evenly distributed in each financial service sectors.

The Financial Services Authority results survey stipulated in the financial literacy index. This is a parameter or the indicator that shows the level of knowledge, skills and communities belief related to financial institutions as well as product and services. Based on the indicator, from 8,000 respondents, it is known that only $21.84 \%$ of Indonesian is classified as well literate (0JK, 2013). This shows the low level of financial literacy in Indonesian. On 
The Impact of Literacy to Shariah Financial Service Preferences Anna Sardiana

population growth, the population of Moslem according to BPS data in 2010 showed that of $87 \%$ or 207.761 .162 people from 237.641 .326 of the Indonesian Moslem population. From its population, 150 million people have an opportunity to access the financial products and services, especially Islamic financial services. In fact, only $2 \%$ who met this. This is known on Islamic banking market share that is still $5 \%$ of the total banking assets in Indonesia as one of the dominant financial services institutions compared to other financial services institutions in Indonesia (analisadaily.com). Therefore, this research would like to see the influence of sharia financial literacy to sharia financial services usage preferences.

The use of financial products or services has done to fulfill individual needs for consuming. So individual preferences in using the sharia financial services is determined by the knowledge and understanding, ability or skills and individual confidence to fulfill the financial needs that is called as financial literacy. Financial literacy is meant as the ability of a person to get, to understand, and to evaluate relevant information on decision-making for understanding its financial consequences (Mason and Wilson, 2000). Financial literacy makes a person able to give decisions based on relevant information. Therefore, the understanding of information becomes important in every decision making process for each individual. Gardner (1999) stated that the understanding is a mental process of adaptation and knowledge transformation.

The understanding of the finance is a process of the individual to get a stimulus messages that originate from all media. After this process, both printed and electronic, then internal individuals in will process it mentally and physically. In the theory of communication effect or known as a SOR theory (Stimulus Organism Response), this is influenced by psychological factors that behavior change depends on the process that occurs on the individual. This is due to the stimulus that delivered to the individual has a possibility to be accepted or rejected. Communication can be good when there is an attention, understanding and acceptance of the stimulus. When those three things 
happened, then the response or the effect is a good understanding. When individual reached understanding level, then this will affect to consumer behaviors. So, on this research, financial literacy becomes independent variables that will be tested its hypothesis in affecting sharia financial services usage preferences.

The consumer attitude toward a products or services, according to the theory of Three component attitude model are determined by three attitude components i.e. cognitive, affective, and conative. From the three components that can affect the attitude are confidence and feelings. On some products or services, attitudes only depend on the confidence, while other products or services attitude depend on evaluation of products or services. Meanwhile, the relationship between attitude and conative or interest can be described as a cause and effect relationship where the attitude of a person can affect to certain moralities (Engel et al.1995). An intention describes the conative attitude components that related to someone preferences to perform regarding specific attitude. Based on some interpretations, conative components can be included the attitude (real) behavior itself (Schiffman, et al. 2000).

In previous research, Al-Tamimi (2009) found a significant impact between financial literacy and investment decision. Besides, Bianco and Bosco (1998) also found that the low of financial literacy couldn't make students to be able to decide investment decisions based on their finances. Sabri and Macdonald (2010) also found that financial literacy have positive effect to the saving behavior. This means that the financial literacy has a significant effect to financial services. Then, based on theory and previous research, this research would like to see the impact of sharia financial literacy to consumer preferences in Islamic finance products and services.

\section{METHOD}

This research is a descriptive research to analyze the influence of sharia financial literacy against your preferences the use of Islamic finance products and services. Based on the background and the formulation of the problem as 
The Impact of Literacy to Shariah Financial Service Preferences Anna Sardiana

well as the characteristics of objects that are examined, so this research is classified using the hypothesis. The source of the data that used in this study is primary data obtained directly from respondents to the survey method.

The statement regarding the knowledge and understanding, skills or ability, and respondents confidence in managing personal finances with regard to Islamic principles and the preferences of respondents in the use of financial services by users and non-users of financial services sharia that spread in several Islamic financial services institution that Islamic banks, Islamic insurance, Islamic capital market products, and pawnshops Islamic and conventional financial services in Jakarta.

In this study, researchers used the entire population of financial services users as a target in the study. The samples using a convenience sampling technique is implemented with regard to the provision of the required data, so that the research carried out on users and non-users Islamic financial services in Jakarta very many and not all users and non-users Islamic financial services are easy to be asked to fill out questionnaires, only users and non-users were considered easy to be asked to fill out questionnaires that will be sampled.

In this study, 220 samples were taken for all non-users and users of Islamic financial products and services in question, i.e. the Islamic banks, Islamic insurance, Islamic capital market and Islamic pawnshops, and other Islamic financial services (financing, BMT, the Pension Fund). Variables in this study are a qualitative that is quantified with Likert scale. Based on the literature study, the variables that are used for analysis are independent variables i.e. the Islamic financial literacy and dependent variable i.e. the Islamic financial services usage preferences. Researchers from various journals and research receive the statement points in the questionnaire on this study. The journals are those directly related to financial literacy, while Islamic principles contained in the statement is an adaptation of several studies on preferences uses Islamic financial services such as banks and others that describe relation to financial services so as to a questionnaire study is to be expected that is not deviated from the basic concepts of financial literacy. 
The tool of analysis that is used in this research is a binary Logit analysis. This is a part of the multiple regression analysis that is used when the dependent variables (response) is a dichotomy variable (categorical). Independent variables that will be used in this research are the sharia financial literacy and then test financial literacy indicator variable by zooming in on the dimensions of knowledge, skills and independent belief variables.

By following the general structure of the binary logit, then equation model that is formed and used in this research is:

1. Sharia financial literacy against sharia financial services usage preferences

$$
\operatorname{Ln}\left(\frac{p}{1-p}\right)=\beta 0+\beta 1_{-} L F
$$

2. Knowledge, capacity, confidence to use sharia financial services

$$
\operatorname{Ln}\left(\frac{p}{1-p}\right)=\beta 0+\beta 1 \_ \text {Knwldge }+\beta 2+\beta 3 \_ \text {Confidence }
$$

\section{RESULT \& DISCUSSION}

In collecting the data, of the 220 sets of questionnaires distributed to users and non-users of Islamic financial services in Jakarta, questionnaires were returned of 213 set by the contents of a complete and incomplete amounted to 7 set. To support the quantitative statistical analysis, descriptive analysis is done qualitatively, especially to explain the demographics of the respondents. Based on the respondents profile statistics in this study, can be drawn that the majority of the study sample, from a total of 213 respondents, the majority of respondents are male with a total of 125 respondents (58.7\%). In terms of age, the majority of respondents were in the category of productive age range between 25-35 years with a number of respondents, 104 respondents (48.8\%) with a composition of 56 users and 48 non-users. This illustrates that the financial service usages level in general in this age range is high enough so that the opportunity to use Islamic financial services is also relatively large when compared to other age ranges category in this study. However, the category of 
The Impact of Literacy to Shariah Financial Service Preferences Anna Sardiana

the age range $36-50$ years have Islamic financial services usage rate is higher than the category age range 25-35 that year. Description of the data is in line with the OJK's financial literacy survey (2013) who found the age category 3550 years is relatively higher compared to the use of financial services category other age ranges. Based on the findings of the OJK (2013) and this research, it explains the level of maturity of age have a positive relationship with referrers use of financial services.

In addition, education also has a positive relationship with the use of financial services, as seen in this study, where education is the majority of respondents in the category D3-D4 degree with a number of 156 respondents (73.2\%), with a composition of 88 respondents are users while the rest, 68 are Islamic financial services non-user respondents. This is in line with the $0 \mathrm{JK}$ survey (2013), which found that respondents with college education background have high utility financial services than other educational categories. This indicates that the level of financial services in the category of higher education has a large portion as seen in the sample of respondents of this study.

As for the occupational category of respondents of this study, is dominated by a draw either by job category teacher / lecturer / civil servants / military / police as many as 70 respondents, or job categories state-owned company (BUMN)/ private sector also 70 respondents. Nevertheless, the proportion of Islamic financial services in the categories of job teacher / lecturer / civil servants / military / police is more i.e. 50 respondents when compared to the employee's job category state-owned company (BUMN)/ private sector only 37 respondents the Islamic financial services in this study. This illustrates the level of need for respondents to use Islamic financial services to the proportion of 152 respondents (71.4\%) of the total 213 respondents.

While based on the monthly expenditure categories of respondents, the majority of respondents are users of Islamic financial services in the categories of expenditure IDR 3,000,001 - IDR 5,000,000 as many as 34 respondents, and 
non-user respondents to the monthly expenditure category IDR 1,000,001$3,000,000$ as many as 42 respondents. This illustrates that the monthly expenditure of respondents have a positive relationship with the use of Islamic financial services. However, this requires further research to prove the positive relationship.

As based on the dependent variables studied were the preference of use Islamic financial services consisting of users and non-users, described the use of Islamic financial services in the form of Islamic banks, Islamic insurance, Islamic capital markets, pawnshops sharia, and institute Islamic financial services such as financing, BMT as well as pension funds sharia, Islamic financial services usage opportunities for non-users.

Preferences use Islamic financial services is measured in a scale of 1-2 where 1 shows that the sample scale did not use (non-users) Islamic financial services and scale 2 shows that a sample of the Islamic financial services. Based on the overall results of the study, from a total of 213 respondents, the Islamic financial services are as much as 118 respondents (55.4\%) and non-users are as much as 95 respondents (44.6\%). As detailed description of the data the frequency of use Islamic financial services in Islamic banks, namely a total of 109 respondents (51.2\%), while non-users of Islamic banks as much as 104 respondents (48.8\%); Islamic insurance, has a non-user frequency of 160 respondents (75.1\%) with the user as much as 53 respondents (24.9\%); Islamic capital market shows how often the Islamic capital market products as much as 20 respondents (9.4\%), while non-users as much as 193 respondents (90.6\%); Islamic pawnshop has a frequency of users as much as 17 respondents (8\%) and non-users by 196 respondents (92\%); while the use of other Islamic financial services such as Islamic Financing, BMT and the Pension Fund of 30 respondents $(14.1 \%)$, while non-users other Islamic financial services in this study were 183 respondents (85.9\%) of the total 213 respondents.

Based on the frequency of sharia financial service usages as has been described previously, the following is a description of the intersection of sharia financial services usages according to the results of research findings: 
Table 1. The Intersection of Sharia Financial Service Usages

\begin{tabular}{|c|c|c|}
\hline The Sharia Financial Service Usages & Frequency & Percent \\
\hline 1. Using All Islamic financial services & 4 & $1.9 \%$ \\
\hline 2. Bank & 43 & $20.1 \%$ \\
\hline 3. Insurance & 7 & $3.3 \%$ \\
\hline 4. Capital Markets & 1 & $0.5 \%$ \\
\hline 5. Pawnshop & 1 & $0.5 \%$ \\
\hline 6. Financing / BMT / Pension Funds & 1 & $0.5 \%$ \\
\hline 7. Bank - Insurance & 21 & $9.8 \%$ \\
\hline 8. Bank - Capital Markets & 6 & $2.8 \%$ \\
\hline 9. Bank - Pawn & 3 & $1.4 \%$ \\
\hline 10. Bank - Financing / BMT / Pension Funds & 5 & $2.3 \%$ \\
\hline 11. Banks - Insurance - Capital Markets & 2 & $0.9 \%$ \\
\hline 12. Banks - Insurance - Pawn & 2 & $0.9 \%$ \\
\hline 13. Banks - Insurance - Financing / BMT / Pension & 10 & $4.7 \%$ \\
\hline Funds & 3 & $1.4 \%$ \\
\hline 14. Bank - Capital Markets - Pawnshop & 3 & $1.4 \%$ \\
\hline 15. Bank - Pawn - Financing / BMT / Pension Funds & 4 & $2.2 \%$ \\
\hline \multicolumn{3}{|l|}{ 16. Bank-Insurance-Ps-Capital Financing / BMT / } \\
\hline Pension Funds & 2 & $0.9 \%$ \\
\hline \multicolumn{3}{|l|}{ 17. Bank-Insurance-Mortgage-Financing / BMT / } \\
\hline \multicolumn{3}{|l|}{ Pension Funds } \\
\hline Total Users & 118 & $55.4 \%$ \\
\hline
\end{tabular}

Source: Primary Data Processed

The Table 1 shows that the Islamic banks dominate the use of Islamic financial services in the study sample. In addition to sampling the Islamic financial services, there is a sample of non-users of Islamic financial services, as mentioned earlier. Non-users can generally be described that each respondent may be users of Islamic banks but not the insurance, capital markets, pawn shops and other Islamic financial services and similarly with the opposite between the Islamic financial services with one another. However, at the same 
time, it can also completely non-users of Islamic financial services, as already mentioned in the description of the frequency of users and non-users of Islamic financial services. The sample frequency as non-users to the opportunities would use Islamic financial services as much as 182 respondents (85.4\%), while non-users who will not use Islamic financial services as much as 31 respondents (14.6\%) of the total 213 respondents. In the case of non-users who did not use any of the types of Islamic financial services, non-users of Islamic financial services dropped to 31 respondents out of 95 respondents as non-users. Thus the chances of non-users who would use Islamic financial services as a whole are 64 respondents. This means that the 64 respondents that have a preference as non-users would use Islamic financial services out of the total 95 respondents non-users and these non-users of the 182 respondents included in the overall non-users who would use Islamic financial services that have not been used each of these respondents in this category.

As for the statistical description of data intended to describe or give particulars of the data or the state of a phenomenon. Drawing conclusions statistical data only refers to an existing data set alone. Based on the independent variables were examined in this study, i.e. Islamic financial literacy, can be described the mean of each Islamic financial literacy indicator variables which was answered by 213 respondents. Islamic financial literacy in the study sample is measured in a scale of 1-5 where 5 higher scale than the scale of 1-4 that indicates the level of knowledge, ability, and confidence will be Islamic financial services. In general, overall it is known that, the average of variable Islamic financial literacy respondents (knowledge, skills and self-confidence) is from 3.49 to 4.55 . It shows that the average respondent had a good enough knowledge about the Islamic financial services system in general, have the ability or good skills in managing personal finances and have such confidence was very good in applying Islamic values on the financial aspects of the private life and in making use of Islamic financial services.

The Influence of the Sharia Financial Literacy to Sharia Financial Service Usage preferences 
The Impact of Literacy to Shariah Financial Service Preferences Anna Sardiana

Model significance test results showed that the variables used Islamic financial literacy affect the variable usage preferences Islamic financial services, so that the model can be used for further analysis. As for the level of closeness and relationship between the variables of the statistical test results, it is known that $\mathrm{R}^{2}$ (Nagelkerke $\mathrm{R}^{2}$ ), which shows the total variation can be explained by the model used, is 7.3\%. That is, the Islamic financial literacy has usage preferences Islamic financial services simultaneously in the range of 7.3\%. While the rest, i.e. by $92.7 \%$ explained by other variables not included in this research model. While the accuracy of the classification used logistic regression models have been quite good for being able to guess correctly 63.4 percent of conditions. In the test model fit, the statistical value of Hosmer and Lemeshow Goodness of fit is 14,025 with a probability of 0081 so that it can be concluded that the model is acceptable in other words, the logistic regression model used has been quite able to explain the data. Furthermore, in the partial test, at a rate of $95 \%$ was obtained statistics Wald for variable financial literacy sharia greater than Chisquare Table degrees of freedom 1 of 1080 and the significance value less than 0.05 , so it was concluded that the factor of financial literacy sharia has influence a real and significant impact on usage preferences Islamic financial services that can be incorporated into the model. The models created are as follows:

$$
\operatorname{Ln}\left(\frac{p}{1-p}\right)=-3.995+0.049 L F
$$

Based on the above model equation, the intercept value of -3.995 means that at the time of the Islamic financial literacy variable i.e. 1. The probability of respondents in using Islamic financial services was $1.8 \%$ if owned Islamic financial literacy is low while the probability of respondents who do not use Islamic financial services are 1 -p or by $98.2 \%$ if the Islamic financial literacy is low.

With the odds ratio of 1.050 means that the respondents had high literacy Islamic finance, have a tendency to use Islamic financial services is 1,050 times compared to respondents who have Islamic financial literacy is low. 
This means that the higher the Islamic financial literacy of consumers, then the probability of use Islamic financial services is also higher.

The test results explain the financial literacy of construction is in line with the theory that has been previously parsed, where a stimulus when through the process of understanding, will produce the response (effect), which in turn will affect the attitude (behavior) of individuals (consumers). Consumer attitudes in preference use Islamic financial services is explained by the theory of Tri Component of Attitude (Engel et al., 1995) that the components that are in a relationship is consistent, where such components reflect cognitive aspects component where consumers have the knowledge and confidence to be a product or Islamic financial services, and aspects of the affective component in which consumers choose to use or not use Islamic financial services to conative component aspects that reflect the consumer the opportunity to change the attitude of non-users into users of Islamic financial services and vice versa.

\section{The Effect of Knowledge, Ability and Confidence Dimension to Islamic Financial Services Usage preferences}

The second model equation will test the effect of each Islamic financial literacy indicator to the Islamic financial services usage preferences. Thus indicators that are used as independent variable in this equation are the knowledge, skills and confidence. Based on the results of significance test model, it can be concluded that simultaneously the knowledge, skills, beliefs significantly influence the preferences of use Islamic financial services with $\mathrm{R}^{2}$ (Nagelkerke $\mathrm{R}^{2}$ ) of 0.119 or $11.9 \%$. As for the rest, amounting to $88.1 \%$ explained by other variables not included in this research model. While the accuracy of the classification in the logistic regression models were used to predict correctly $62 \%$ of conditions.

The test is based on the model and parameters, statistics indicate that the magnitude of the value of Hosmer and Lemeshow Goodness of fit for 6962 with a probability or sig. 0541 so it was concluded that the logistic regression model used has been quite able to explain the data. In the partial test, formed the model equations are: 
The Impact of Literacy to Shariah Financial Service Preferences

Anna Sardiana

$\operatorname{Ln}\left(\frac{p}{1-p}\right)=-3.742+0.188 \_K n w l d g e-0.056 \_$Ability $+0.032 \_$Confidence

Based on logistic regression analysis on the partial test above, the intercept value of -3.742 means that when the variable of knowledge, ability and confidence value is 1 , that the respondent did not have the knowledge, ability and confidence, then the probability of the use of Islamic financial services by 0.024 or $2.4 \%$. While the probability of respondents who did not / do not use Islamic financial services amounted to $97.6 \%$ if the knowledge, skills and confidence regarding its sharia financial is low.

As the construction of financial literacy, knowledge dimension, and the dimension of the application which are the ability and confidence as indicators in measuring the level of an individual's financial literacy. So it becomes important to look beyond the influence of each indicator on the Islamic financial services Usage preferences.

In Islamic financial literacy equation model which influences the Islamic financial service Usage preferences has described the level of the relationship and significance of the Islamic financial literacy effect on the Islamic financial services Usage preferences. While the influence of the Islamic finance knowledge equation, ability and confidence on the Islamic financial service Usage preferences, only the knowledge that significantly affect to Islamic financial services Usage preferences. As for the ability and self-confidence does not significantly affect to the Islamic financial service Usage preferences because it has a $p$-value above 0.05 .

It is clear that although as a construction, financial literacy affects consumer preferences in using a product or service, in further analysis, not all dimensions that make up the construction of financial literacy that will influence consumers to use the product or service as seen on the dimensions of the application i.e. the ability and confidence that does not significantly affect the Islamic financial service usage preferences. Thus, it can be concluded that on the construction of the Islamic financial literacy, only the dimensions of 
knowledge that significantly affects to the Islamic financial service usage preferences.

As for the comparison among two models of the equation, the knowledge has larger odd ratio when compared to the Islamic financial literacy, where it is clear that respondents have high knowledge, have a tendency to use Islamic financial services 1.207 times compared to respondents who have low knowledge. This means that the higher consumer's knowledge, and then the probability of use Islamic financial services is also higher.

\section{The influence of the Sharia Financial Literacy to Sharia Bank Usage Preferences}

The third model examines the influence of Islamic financial literacy to the Islamic banks usage preferences, so the Islamic banks that made as the dependent variable in this equation is replacing the Islamic financial services. In the test model significance, with a significance level of 5\% Islamic finance literacy variable which is used affects the Islamic banks usage preferences, with the level of closeness and relationships between variables in $\mathrm{R}^{2}$ (Nagelkerke $\mathrm{R}^{2}$ ) i.e. 0.085 or $8.5 \%$, showing a total contribution of sharia financial literacy in explaining the diversity of Islamic bank usage preferences variables involved. As for other $91.5 \%$ is explained by other variable that is not included in this research model. In addition, the logistic regression model that has been used is good for being able to predict correctly 62 percent of the conditions. Test models and parameters indicate that the magnitude of the statistical value Hosmer and Lemeshow Goodness of fit with a probability of 15.426 or sig. 0.051 so it can be concluded that the model is acceptable. In other words, the logistic regression model that has been used is quite able to explain the data. In the partial analysis test results proved that the Islamic financial literacy variables significantly influence the Islamic bank variable usage preferences with models created:

$$
\operatorname{Ln}\left(\frac{p}{1-p}\right)=-4.527+0.053 L F
$$


The Impact of Literacy to Shariah Financial Service Preferences Anna Sardiana

Based on this model, with the intercept value of -4.527 means that when the Islamic financial literacy variable is 1, respondents who have Islamic financial literacy own lower probability of using Islamic banks by $1.1 \%$, while the probability of respondents who have not used Islamic banks i.e. $98.9 \%$ if the Islamic financial literacy is low. It can be concluded that Islamic financial literacy significantly affects Islamic banks usage preferences. In other words, the higher of respondent's Islamic financial literacy the more likely the Islamic banks usage becomes 1.054 times.

\section{The Influence of Sharia Financial Literacy to Sharia Insurance Usage Preferences}

The fourth model is test results influence of sharia financial literacy to sharia insurance usage preferences. So, sharia insurance becomes a dependent variable on this equation. On the review of the model significance, sharia financial literacy affects sharia insurance usage preferences with closeness level and the relationship between the variables in $R^{2}$ (Nagelkerke $R^{2}$ ) of 0.022 or $2.2 \%$. So the total variation that can be explained through this model is $2.2 \%$. While the rest, amounting $97.8 \%$ has been influenced or explained by other variables, which are not included on this research model.

On partial analysis and modeling of the Islamic financial literacy effect against sharia insurance usage preferences, a significance level of $10 \%$ Wald statistic for variable Islamic financial literacy is larger than Chi-square Table degrees of freedom 1 of 1.061 and the significance value is smaller than 0.1 , so it can be concluded that the Islamic financial literacy has a significant impact on sharia insurance usage preferences, the model is formed:

$$
\operatorname{Ln}\left(\frac{p}{1-p}\right)=-3.582+0.028 L F
$$

Based on the model, the intercept value of -3.582 means that when the Islamic financial literacy variable is 1 , that the respondent has Islamic financial literacy is low, the respondent has a probability of sharia insurance usage of 0.028 or $2.8 \%$ while the probability of respondents who do not use sharia insurance is $97.2 \%$ if the Islamic financial literacy is low. 


\section{Discussion}

The results of this research showed that 75.2 percent samples have the sharia financial service usage preferences. This is consistent with the research that has been done by the Research Department SEF UGM (2012), Maski (2010) and Wahyuningsih (2005), which shows that the majority of the samples have the sharia financial service usage preferences. However, there are differences in the sharia financial services usage preferences that tested. The previous research examined sharia banks preferences user and conventional banks with each division each $50 \%$ samples as the research object while this research using the users and non-users of sharia financial services as a sample of research. This is different with the findings on Nova (2011) and Jonah (2004), which indicates the lack of sharia financial services usage preferences due to the weakness knowledge level research samples on sharia banks.

When compared to the preference of financial services in general in Sabri and Macdonald (2010), Al-Tamimi and Kalli (2009) there was indeed an indication of the preference of use of financial services by banks and the capital market as the main target. Regarding similarities population, Maski (2010), Wahyuningsih (2005), Nova (2011), and Yunus (2004) used the banking industry as the population in their research. Al-Tamimi and Kalli (2009) used capital market investors, while the SEF UGM Research Department (2012), Sabri and Macdonald (2010) used the students as the population. While this research users and non-users use Islamic financial services as the study population, in general, it can be concluded that the results of financial services usage preferences in this study are consistent with other studies in the financial services usage preferences.

As a comparison to the Islamic financial literacy variables, results of this study indicate that the Islamic financial literacy has a significant influence on the preference of the Islamic financial services usage with a coefficient of 0.068 . Islamic financial literacy has three dimensions which explain its effect on usage preferences Islamic financial services such as: knowledge, ability, selfconfidence. As described in the analysis of the research data, each dimension 
The Impact of Literacy to Shariah Financial Service Preferences

Anna Sardiana

showed that the average Islamic financial literacy in this study are in the range of 3.48 to 4.59 illustrates that Islamic financial literacy of respondents fairly good to very good. This indicates that in addition to other variable, which is not included in this study model, collaboration among the dimensions of knowledge, ability and self-confidence that constructed to Islamic financial literacy contribute to the growth of Islamic financial services. Consistent with this research, other studies that discuss financial literacy in general proved that financial literacy significantly influence the financial services usage preferences Chen and Volpe (1998) and Louw, Fouche and Oberholzer (2013). Where the study sample population both Chen and Volpe (1998) and Louw, Fouche and Oberholzer (2013) was among the students. However, in general it shows that financial literacy has significant effect the financial services usage preferences.

In addition, Al-Tamimi and Kalli (2009) used United Arab Emirates's investor as research population. In the study, Al-Tamimi and Kalli (2009) found that financial literacy significantly influence the investment decisions of individual investors, which it relates to the use of financial services as the dependent variable. The different things are the researches, which are not consistent with Alqayadi Ibrahim (2013), which states that financial literacy is not a significant effect on the use of financial services. This is due to the policy in the country where the study sample (Alqayadi Ibrahim, 2013) is a non-resident population and the United Arab Emirates. The differences in the results that were described above may be occurring because: First, differences in population. Second, differences in the independent variable. Third, difference in the research field time.

\section{CONCLUSION}

Based on the results of the discussion and analysis of data, it could be concluded that will answer the research questions. First, there is a significant relationship among Islamic financial literacy on the Islamic financial services usage preferences. The indicator is based on financial literacy, which is the dimension of knowledge, ability and self-confidence; the dimensions of 
knowledge significantly affect Islamic financial services usage a preference. Second, This means that the higher the sharia financial literacy of consumers, then the probability of Islamic financial services usage is also higher. So with the increase of Islamic financial literacy, the prospect of the use of Islamic financial services in the future will also increase.

\section{REFERENCES}

Bianco, C.A. et.al. (2012). Financial (IL) Literacy of College Student. The Journal of American Academy of Business Cambridge, Vol.18 (1), pp. 25-34.

Chen, H. et.al. (1998). An Analysis of Personal Financial Literacy Among College Students. Financial Services Review,Vol. 7 No. 2, pp. 107-128.

Gardner, H. (1999). Intelligences Reframed: Multiple intelligences for the 21st century. New York: Basic Books.

Huston, S.J. (2010). Measuring Financial Literacy. Journal of Consumer Affairs, Vol. 44 Issue 2, pp. 201-210.

Ibrahim, M.E. \& F.R. Alqayadi. (2013). Financial Literacy, Personal Financial Attitude, and Forms of Personal Debt Among Residents of UAE. International Journal of Economics and Finance, Vol. 5 (7), pp. 501-512.

Louw, J. et.al. (2013). Financial Literacy Needs of South African Third-Year University Students. International Business and Economic Research Journal, Vol 12, Number 4, pp. 411-420.

Maski. (2010). Analisis Keputusan Nasabah Menabung (Decision Analysis of Client Savings). Journal of Indonesian Applied Economics, Vol. 4 (1), pp. 43-57.

Nova, Y. (2011). Pengaruh Pengetahuan, Tingkat Pendidikan dan Pendapatan Terhadap Preferensi Nasabah dalam Mengambil Keputusan Menjadi Nasabah Bank Syariah (The influence of the knowledge of the level of education and income of Customer Preferences in making decisions a customer of sharia banks) (Unpublished Thesis). Depok: Universitas Indonesia. 
The Impact of Literacy to Shariah Financial Service Preferences

Anna Sardiana

OJK. (2013). Strategi Nasional Literasi Keuangan (National Strategy Financial Literacy). Jakarta, Directorate of Information and Education 0JK.

OJK. (2013). Seri Literasi Keuangan: Perencanaan Keuangan Ibu Rumah Tangga

(Financial Literacy Series: Financial Planning Housewife). Jakarta, Directorate of Information and Education OJK.

Sabri, M.F. \& M. MacDonald. (2010). Saving Behavior and Financial Problems Among College Students: The Role of Financial Literacy in Malaysia, Cross Cultural Communication, Vol.6 No.3, 2010, pp. 103 - 110.

Tamimi, Hussein, A. Hassan, Al Anood Bin Kalli. 2009. Financial Literacy and Investment Decision of UAE Investor. The Journal of Risk Finance, Vol. 10 No. 5.

Tamimi, H. (2006). Factors influencing individual investor behavior: an empirical study of the UAE financial markets. The Business Review, Vol. 5 No. 2, pp. 225-32.

Volpe, R. et.al. (2002). A Survey of Investment Literacy Among On-line Investors. Financial Counseling and Planning, Vol. 13 No. 1, pp. 1-13.

Wahyuni, S.D.S. (2005). Preferensi Nasabah Pegadaian Syariah (Customer Preference of Sharia Pawnshop). (Unpublished Thesis). Depok: Universitas Indonesia.

Wahyuningsih, I. (2005). Preferensi, Sistem Sosial, Sikap dan Keinginan Berperilaku Konsumen Dalam Memilih Bank Syariah (Preferences, Social System, Attitudes and Desire Behave Consumers in Selecting Sharia Banks). (Unpublished Thesis). Depok: Universitas Indonesia. 